О.В. Іщенко

\section{А.О. Юхименко}

І.П. Кошова

С.І. Ільченко

Д.О.Степанський

Державний заклад

«Дніпропетровська медична академія

Міністерства охорони

здоров'я України»
DOI: https://doi.org/10.26641/1997-9665.2019.3.40-47

УДК 615.28:579.861.2:579.61:616-078

БІОПЛІВКОУТВОРЮЮЧІ ВЛАСТИВОСТІ КЛІНІЧНИХ ІЗОЛЯТІВ PSEUDOMONAS AERUGINOSA, ВИДІЛЕНИХ ВІД ДІТЕЙ ХВОРИХ НА МУКОВІСЦИДОЗ, ТА МОЖЛИВОСТІ ВПЛИВУ ВАCILLUS SUBTILIS HA HИX IN VITRO

Надійшла: 28.07.2019

Прийнята: 24.08 .2019

Ishchenko O.V. iD $₫$, Yukhymenko A.O., Koshova I.P. iD, Ilchenko S.I. iD, Stepanskyi D.O. iD Biofilm-forming properties of clinical isolates Pseudomonas aeruginosa collected from children with Cystic Fibrosis and potential Bacillus subtilis impact in vitro.

State Institution «Dnipropetrovsk Medical Academy of Health Ministry of Ukraine», Dnipro, Ukraine

ABSTRACT. Background. Pseudomonas aeruginosa infection determines clinical prognosis in patients with Cystic Fibrosis. Mucoid strains of $P$. aeruginosa are capable of forming biofilms and growing in them. Given the multiple resistance of microorganisms forming biofilms, the perspective of using Bacillus spp.for the purpose of sanitizing surfaces where pathogens may persist is being discussed. Objective. To study the biofilm-forming ability of $P$. aeruginosa clinical isolates from children with Cystic Fibrosis and to determine the impact of B. subtilis on them in vitro. Methods. Sputum and/or mucus samples from a deep smear from the posterior pharyngeal wall were collected from children with Cystic Fibrosis. Bacteriological, microscopic, biochemical and statistical research methods were used. The antagonistic properties of $P$. aeruginosa and $B$. subtilis were studied by the method of delayed antagonism and inco-cultivation experiments in a liquid nutrient medium followed by inoculation serial dilutions. Biofilm forming ability was determined by express-method using 96-well plates. Results. Bacteriological surveysshowed that $P$. Aeruginosa was isolated from $34.21 \%$ (95\% CI 32.50-35.92) of samples. It was found that $B$. subtilis has direct moderate antagonism against $P$. aeruginosa in the delayed antagonism studyas well asafter their co-cultivation in a liquid nutrient medium.After co-cultivation the abundant growth of bacilli in all experiments at all repetitions as well as limitation of the $P$. aeruginosa growth was showed. The biofilm formation wasdetermined in 76.92\% (95\% CI 73.02-80.77) of $P$. aeruginosa clinical isolates, and in $100 \%$ of $B$. subtilis samples The B. subtilis was able to form biofilm in the presence of $P$. aeruginosa in most cases during co-cultivation experiments. Conclusion. Clinical isolates of $P$. aeruginosa isolated from children with Cystic Fibrosis are moderately susceptible to $B$. subtilisin vitro. Biofilm formation of $P$. aeruginosa can be suppressed by $B$. subtilis in vitro.

Key words: cystic fibrosis, $P$. aeruginosa, mucoid phenotype, biofilm, B. subtilis, antagonism.

\title{
Citation:
}

Ishchenko OV, Yukhymenko AO, Koshova IP, Ilchenko SI, Stepanskyi DO. [Biofilm-forming properties of clinical isolates Pseudomonas aeruginosa collected from children with Cystic Fibrosis and potential Bacillus subtilis impact in vitro]. Morphologia. 2019;13(3):40-7. Ukrainian.

DOI: https://doi.org/10.26641/1997-9665.2019.3.40-47

Ishchenko O.V. 0000-0001-6350-8176

Koshova I.P. 0000-0002-5631-8005

Ilchenko S.I. 0000-0003-2181-1833

Stepanskyi D.0. 0000-0001-6350-8176

$\triangle$ med.oksana2017@gmail.com

() SI «Dnipropetrovsk Medical Academy of the Ministry of Health of Ukraine», «Morphologia»

\section{Вступ}

Муковісцидоз (МВ) - генетичне захворювання 3 аутосомно-рецесивним типом успадку- вання, поширене в усіх етнічних групах, і $\epsilon$ найчастішою спадковою патологією у світі. Природний перебіг МВ тяжкий, і без лікування 
більш ніж 80\% випадків закінчуються летально у перші роки життя [1].

Причиною захворювання $\epsilon$ наявність мутацій в гені трансмембранного регуляторного білка муковісцидозу (ТРБМ). Порушення іонного транспорту через дисфункціюТРБМ призводять до дегідратації та ацидифікації слизових оболонок, підвищення в'язкості бронхіальної секрету, зниженню мукоциліарного кліренсу, обтурації дихальних шляхів в'язким слизом, що створює умови для хронічної бронхолегеневої інфекції та запалення, які є основною причиною захворюваності та смертності серед пацієнтів 3 MB [1-4].

Важкий перебіг захворювання, 3 ранньою маніфестацією легеневих проявів і раннім інфікуванням $P$. aeruginosa характерний для хворих гомозиготних по мутації F508del [2,5]. Повідомляють, що до 80\% дорослих інфіковані синьогнійною інфекцією. В чисельних дослідженнях доведено, що чим довше пацієнт залишається неінфікованим $P$. aeruginosa, тим більшою залишається очікувана тривалість життя [5].

Адгезія до клітин епітелію у $P$. aeruginosa реалізується мікроворсинками, а іï нейрамінідаза полегшує специфічну взаємодію. Бактерії Pseudomonas spp. утворюють капсулу полісахаридної природи та синтезують альгінат, що захищає їх від протимікробної дії. Ферменти та токсини мікроорганізму обумовлюють некроз стінок альвеол, дрібних бронхів та судин, що призводить до розвитку тромбозу і крововиливів. Бактеріальний васкуліт на ряду 3 дефектом ТРБМ відіграє провідну роль у персистенції збудників [6-8].

Ключовим при МВ є саме мукоїдний фенотип $P$. aeruginosa. Мукоїдні штами здатні до формування біоплівок та росту в них. Для хронічної $P$. aeruginosa-інфекції в дихальних шляхах характерно існування біоплівок в анаеробних умовах густого слизу $[1,3,8]$. Біоплівки організовані бактеріальні консорціуми клітин,у складі яких існування клітини істотно відрізняється від такого у планктонній формі [610]. Біоплівки синьогнійної палички в 8-32 рази більш стійкі до дії усіх класів бета-лактамів в порівнянні 3 мікроорганізмами, що не утворюють біоплівок [8].

Основним структурним компонентом біоплівок $є$ матрикс, представлений мікробними екзополісахаридами, білками і гліколіпідами. Клітини у плівці упорядковані у вигляді грибоподібних утворень і «стовпів», «цементованих» екзополісахаридами. Матрикс розділений каналами, заповненими водою, має порожнини. По каналах транспортуються поживні речовини та кисень, видаляються продукти життєдіяльності бактерій.У глибоких шарах розташовуються клітини, метаболізм яких переклю- чений на анаеробний тип дихання. «Зрілі» плівки постійно виділяють у оточуюче середовище планктонні клітини і цілі фрагменти, здатні вкривати біоплівкою нові поверхні.

Взаємостосунки окремих субпопуляцій мікроорганізмів у складі біоплівки регулюються механізмом міжклітинних комунікацій «quorumsensing». Він функціонуе через продукцію бактеріальними клітинами сигнальних молекул, які забезпечують колективну координацію експресії i репресії генів в мікробній популяції, забезпечуючирегуляцію складу бактеріальної популяції.

Бактеріальні клітини, вкарбовані у матрикс, захищені від зовнішніх впливів і відрізняються високим рівнем толерантності до дії факторів імунітету та протимікробних засобів. Полімери матриксу виконують рольмолекулярного фільтру, що запобігає хімічним впливам на клітини [6-10]. Гліцерол-фосфорильованібетаглюкани $P$. Aeruginosa активно сорбують дрібні молекули протимікробних засобів. У полімікробних плівках антибіотикорезистентні клітини виділяють ензими та антибіотикзвязуючі протеїни, а висока щільність мікробної популяції стимулюе обмін генетичною інформацією, у т.ч. детермінантами антибіотикорезистентності. Клітини-персистери - метаболічно неактивні субпопуляції в складі біоплівки, в яких відсутні процеси біосинтезу, що робить їх невразливими до дії антибіотиків і хіміопрепаратів. Таким чином, можливості впливу на патогени, що знаходяться у складі біоплівки, істотно обмежені [7, 10]. Саме такі біоплівкоутворюючі ізоляти сприяють розвитку хронічного запалення, при якому патологічний процес може тривати десятиліттями $[7,8]$.

Джерелом інфекції для дитини з МВ є хворий або бактеріоносій, який виділяє $P$. aeruginosa, забруднені нею поверхні виробів медичного i загального призначення [6].Загальноприйнятим та ефективнимпідходом для вирішення зазначеної проблеми є застосування дезінфектантів [11].

3 огляду на труднощі лікування інфекції, викликаної P. aeruginosa, цікаво було дослідити альтернативний метод впливу на іiі біоплівки. Заслуговують уваги повідомлення про високу ефективність обробки поверхонь в закладах охорони здоров'я 3 використанням пробіотичних бактерій Bacillus spp. [12-17]. Зокрема, Vincenza La Fauci та ін. (2015) встановили достовірне зниження біонавантаження на тест-поверхні на 92,22 -99,99\% через 24 години після застосування детергенту; а в польових випробуваннях відзначали, що навіть при поточному використанні поверхніз неї не виділяється Enterococcusfaecalis, Candidaalbicans, Pseudomonasaeruginosa, Acinetobacterbaumannii, Klebsiellapneumoniae [14]. В багатоцентровому 
проспективному дослідженні показали, що використання детергенту 3 Bacillus spp. було достовірно пов'язане зі зниженням загальної захворюваності на інфекції, пов'язані з наданням медичної допомоги, відмічали достовірне стабільне зменшення патогенних мікроорганізмів на оброблюваних поверхнях i зниження експресії генів стійкості до лікарських засобів в порівнянні зі звичайним дезінфектантом [15].

Враховуючи парадигму існування мікроорганізмів в умовах біоплівок (перш за все, 3 огляду на їх множинну резистентність) нас зацікавила можливість дослідити здатність клінічних ізолятів $P$. aeruginosa від дітей з $\mathrm{MB}$ та B.subtilis до утворення біоплівок та можливий антагоністичний вплив B.subtilisна біопівкоутворюючі властивості $P$. aeruginosainvitro.

Мета роботи: вивчити біоплівкоутворюючі властивості клінічних ізолятів P.aeruginosa, виділених від дітей з МВ, та вплив на них $B$. Subtilis in vitro.

\section{Матеріали та методи}

Для дослідження взято 76 зразків мокротиння та/або слизу з глибокого мазку 3 задньої стінки глоткивід 24 пацієнтів, хворих на MB, віком від 1 до 17 років.

В ході дослідження використовували методи:

- бактеріологічний 3 виділенням чистої культури $P$. aeruginosaтa B. subtilis;

- мікроскопічний - світлова та фазовоконтрастна мікроскопія;

- біохімічний - для дослідження біологічних властивостей мікроорганізмів та іiі ідентифікації;

- вивчення здатності до утворення біоплівок $P$. aeruginosaтa B. Subtilis експресметодом 3 використанням 96-луночних планшетів;

- вивчення антагоністичних властивостей B. Subtilis до $P$. aeruginosa методом відстроченого антагонізму, спільного культивування та при культивуванні біоплівок;

- статистично-аналітичні для оцінки достовірності відмінностей між одержаними даними.

Вивчення відстроченого антагонізму за методикою перпендикулярних штрихів. Суспензію бацил (0,5 за стандартом мутності McFarland) наносили петлею у вигляді смужки товщиною 2 мм на дно чашки Петрі з м'ясо-пептонного агару (МПА). Посіви інкубували в термостаті при температурі $37,0^{\circ} \mathrm{C}$ протягом 24 годин. Для визначення антагоністичної активності до культури, що виросла, підсівали перпендикулярним штрихом суспензії культур $P$. aeruginosa в 0,85 $\%$ розчині натрію хлориду товщиною 1 мм (0,5 за стандартом мутності McFarland).
Облік результатів дослідження проводили через 18 годин інкубування в термостаті при температурі $37,0^{\circ} \mathrm{C}$ за розміром зон пригнічення росту культур $P$. aeruginosa. Провели 12 тестів. Контролем росту був їх паралельний висів на МПА без дослідного ізоляту.

Результати оцінювали за гальмуванням росту $P$. aeruginosa: зони затримки росту $0-5$ мм (-) - неактивні, 6-10 мм (+) - помірно активні, 1115 мм (++) - активні, більше 16 мм (+++) високоактивні. Відповідно антагоністичну активність B. subtilis оцінювали як «відсутню», «слабку», «помірну» та «сильну».

Вивчення антагоністичних властивостей на рідкому поживному середовищі. Готували суспензії культур $P$. aeruginosa та B. Subtilis 1,0 за стандартом мутності за McFarland. Далі в 1 млм'ясо-пептонного бульйону (МПБ) вносили готові суспензії культур $P$. aeruginosa та $B$. subtilisв кількості 100 мкл кожна. Спільну культивацію проводили в термостаті протягом 18 годин при температурі $37^{0} \mathrm{C}$.

Отриману мікробну суспензію в кількості 100 мкл послідовно серійно розводили в МПБ 3 коефіцієнтом розведення 10. 3 вихідної кількості клітин отримали серію $10^{2}-10^{12}$ на 1 мл. Суспензію мікроорганізмів 3 серійних розведень в кількості 100 мкл інокулювали на поверхню МПА одразу після приготування одночасно на 4 чашках Петрі для кожного розведення.

Облік результатів проводили після 24 год. інкубації в термостаті при температурі $35^{\circ} \mathrm{C}$ шляхом підрахунку кількості колоній $P$. aeruginosa та B. subtilis 3 урахування ступеня розведення.

Паралельно проводили інкубацію чистих культур з подальшим висівом на МПА для контролю їх росту.

Результати оцінювали за пригніченням росту тест-культури в порівнянні з контролем.

Біоплівкоутворююча здатність $P$. aeruginosa та B. Subtilis та їх взаємний антагоністичний вплив

Констатацію явища формування біоплівки проводили у стаціонарній системі експресметодом з використанням 96-луночного планшету. Спершу вивчали здатність чистих культур $P$. aeruginosaта B. Subtilis утворювати біоплівку. Далі - здатність $P$. aeruginosa утворювати біоплівку в присутності Bacillus spp. Для одного зразка одночасно використовували по 5 лунок. Дослід повторили 5 разів.

Добову культуру суспендували в стериль-

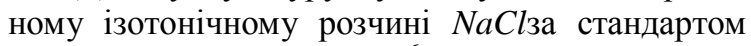
мутності McFarland $1 \times 10^{6}$ КУО/мл. Отриману суспензію по 50 мкл вносили у лунки планшету, що містили 150-200 мкл поживного бульйону. Інкубацію проводили в термостаті за температури $37^{0} \mathrm{C}$ протягом 72 годин. Після закінчення інкубації залишки живильного середовища обе- 
режно відбирали шприцом, а лунки промивали тричі ізотонічним розчином $\mathrm{NaCl}$. Якщо лишалася плівка, мікроорганізм вважали біоплівкоутворюючим.

Утворені біоплівки обережно знімали бактеріологічною петлею, поміщали на знежирене предметне скло, фіксували етиловим спиртом та висушували протягом 30 хв.

Далі препарат фарбували протягом 15 хв. насиченим водним розчином Конго червоного, промивали проточною водою та висушували.

Потім препарат дофарбовували протягом 6 хв. $10 \%$ розчином карболового фуксину, повторно промивали під проточною водою та висушували.

Для візуалізації утворених біоплівок використовували імерсійну систему світлового мікроскопу (збільшенням х 900).

Планктонні клітини бактерій у результаті фарбування карболовим фуксином мали пурпурний колір, а пофарбований Конго червоним матрикс (бактеріальний екзополісахарид та білок) рожевий.

\section{Результати та їх обговорення}

При бактеріологічному дослідженні встановили, що P. Aeruginosa виділяється 3 34,21\% (95\% ДІ 32,50-35,92) ізолятів. Треба зазначити, окрім ізолятів 3 типовими культуральними та морфологічними властивостями, зустрічалися й такі,що не утворювали специфічний пігмент; ряд ізолятів мав мукоїдним фенотип, а також змінену хіміотерапевтичною чутливість до беталактамних антибіотиків. Саме тому особлива увага була приділена чутливості виділених ізолятів до антагоністичної дії бацил.

Результати дослідження відстроченого антагонізму методом перпендикулярних штрихів між $P$. aeruginosa та $B$. Subtilis продемонстрували, що B. subtilis володіють прямим помірним антагонізмом по відношенню до $P$. aeruginosa, зона затримки росту склала 8,55 мм(95\% ДІ 8,128,98).

Результати вивчення антагонізму в рідкому поживному середовищі співзвучні з даними, отриманими за попередньою методикою. Культури $P$. aeruginosaвиявилися помірно чутливими до дії бацил. При посіві серійних розведень отримано помірний ріст $P$. aeruginosa $1,94 \lg$ КУО/мл (95\% ДІ 1,84 - 2,04), та спостерігали деяке обмеження росту B. subtilis до 5,01 lg КУО/мл (95\% ДІ 4,91 $5,11)$. Для порівняння в контрольних висівах отримали 8,06 lg КУО/мл $(95 \%$ ДІ 7,66-8,46) і 8,18 $\lg$ КУО/мл (95\%ДІ 7,77-8,59) відповідно.

Таким чином, при спільній культивації в рідкому поживному середовищі показано конкуруючу взаємодію за типом прямого антагонізму між B. subtilis.та $P$. aeruginosa. Культура пробіотичних бацил давала рясний ріст в усіх дослідах при всіх повтореннях, обмежуючи ріст $P$. aeruginosa.
Серед виділених ізолятів $P$. aeruginosa експрес-методом встановлено здатність до біоплівкоутворення в 76,92\% (95\% ДІ 73,0280,77) випадків.

Особливості утворення біоплівок клінічними ізолятами $P$. aeruginosa, виділених від дітей, хворих на МВ, ілюстрованірис. 14.Урахування результатів дослідів проведені на 24, 48, 72 та 96 годинах культивації. В нашому дослідженні на початкових стадіях плівко утворення $P$. Aeruginosa відмічали утворення розеток i тяжів, які в подальшому зливаються у багатоклітинні конгломерати, 3 їх наступним перетворенням в острівці більшого розміру.

На кінець першої доби відмічали появу бактеріальнихконгломератів, що являли собою утворення неправильної форми (рис 1a i 1b).Процес утворення бактеріальної плівки був багатоцентровим. Щільність укриття бактеріальними конгломератами P. Aeruginosa по завершенні першої доби культивування відображає рис. 1b. Дрібними, неправильної форми утвореннями була рясно вкрита майже уся поверхня, охоплена полем зору. При цьому більшість елементів відособлені, в окремих локусах спостерігається злиття елементів 3 тенденцією до утворення ущільнених островків, яких на цьому етапі плівкоутворення обмаль.

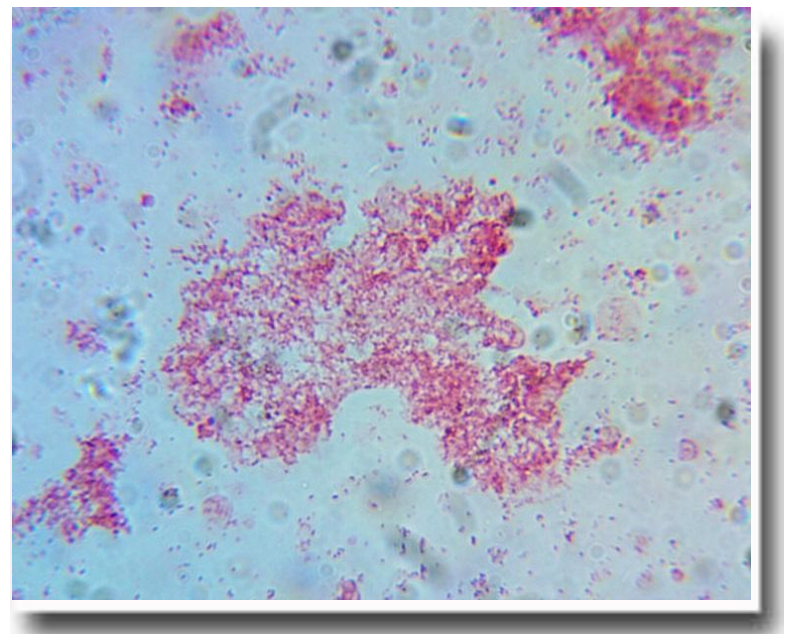

Рис. 1а. Біоплівка P. aeruginosa на кінець першої доби культивації. Фарбування фуксином. ×900.

Після 48-ми годинного культивування (рис. 2)значна площа поверхні укритаутвореннями різної неправильної форми 3 нерівним краєм, згрупованими по кілька елементів, схильними до злиття у ще більші острівки. Щільність цих утворень, у порівнянні із конгломератами,спостереженими на першу добу, дозволяє припустити, що збільшення структурних елементів відбувається у трьох вимірах.

По завершенні третьої доби культивування (рис. 3) спостерігали збільшення кількості описаних вище островків, зменшення простору між окремими фрагментами біоплівки. Тяжі між 
різними ділянкамивитягувались та стали щільними, спрямовані на замкнення сітчастої структури біоплівки.

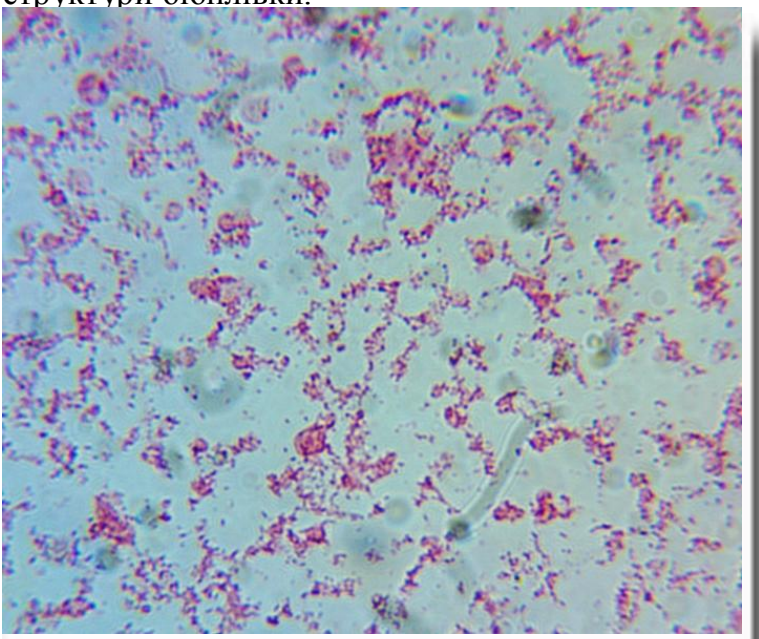

Pис. 1b. Біоплівка $P$. aeruginosa на кінець першої доби культивації. Фарбування фуксином. $\times 900$.

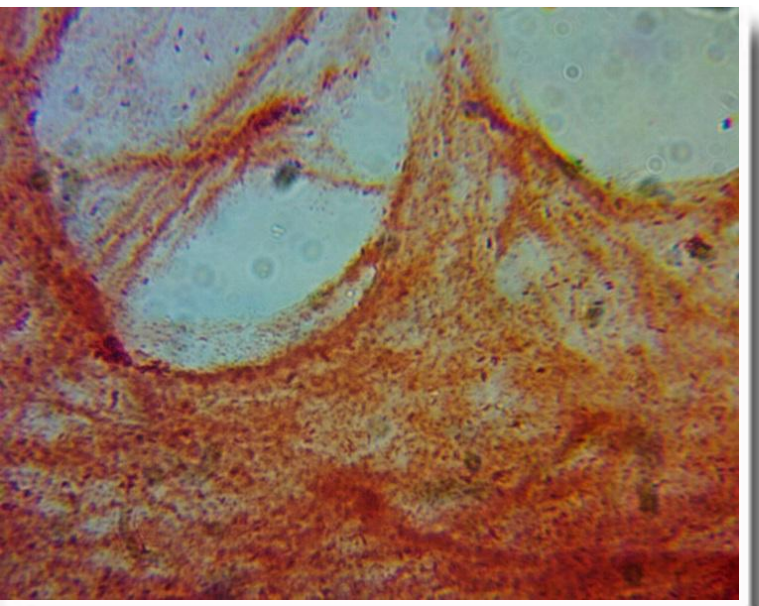

Рис. 2. Біоплівка P. aeruginosa після 48 годин культивування.Забарвлення фуксином. $\times 900$.

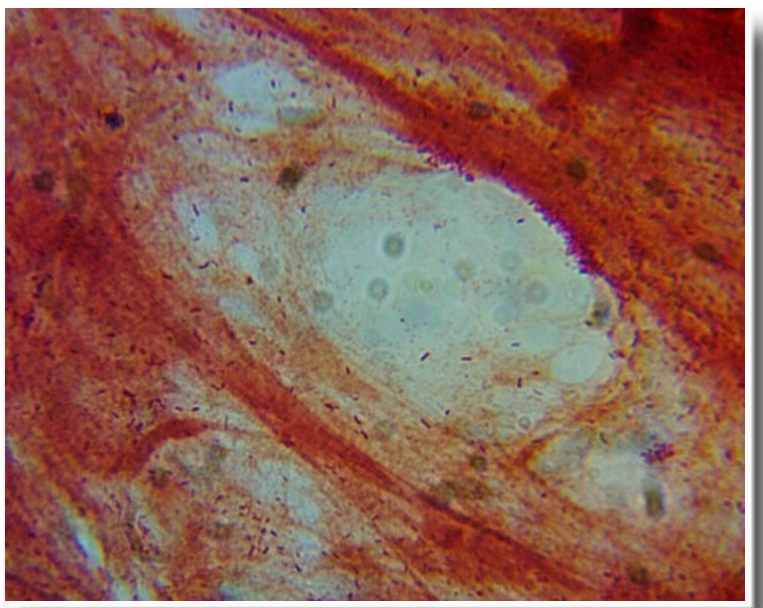

Pис. 3. Біоплівка P. Aeruginosa після 72-х годин культивування. Забарвлення фуксином. $\times 900$.

На четверту добу культивування (рис.4) за- вершення формування біоплівки візуально характеризувалось утворенням суцільно пов'язаної сітчастої системи без окремо розташованих елементів, що являла собою практичнооднорідну структуру. Біоплівку не можна було назвати моношаром, оскільки у піi структурі залишались вільні зони. Неоднорідність забарвлення спостережених структур дозволяе припустити наявність у структурі плівки площин, заповнених бактеріальним екзополісахаридним матриксом.

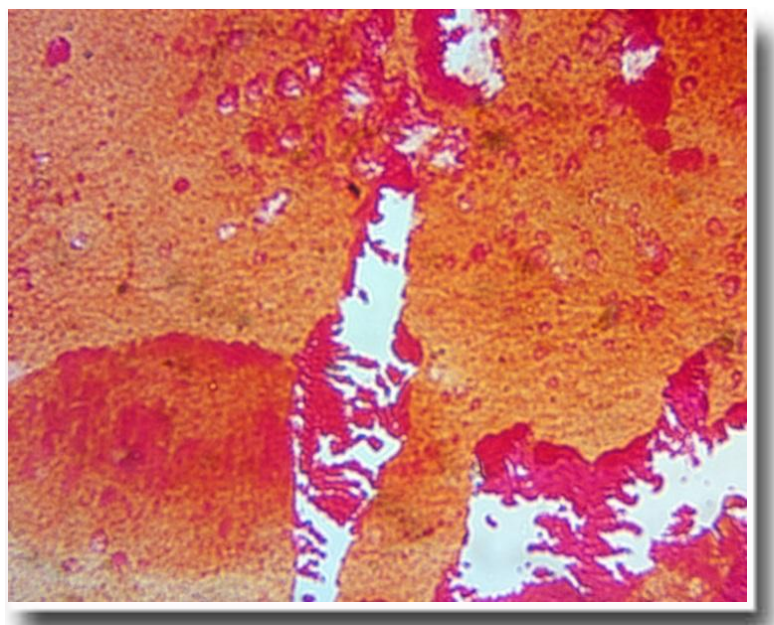

Pис. 4. Біоплівка $P$. aeruginosa на кінець 4-ї доби культивування. Забарвлення фуксином. $\times 900$.

Чиста культура B.subtilis формувала макроскопічно білу плівку з дрібним рельєфом в усіх лунках при повторних експериментах, тобто у 100\% випадків. Мікроскопічно вони складаються 3 ланцюгів, утворених клітинами, які переплітались 3 утворенням трьохвимірної сітки (рис. 5, 6, 7).

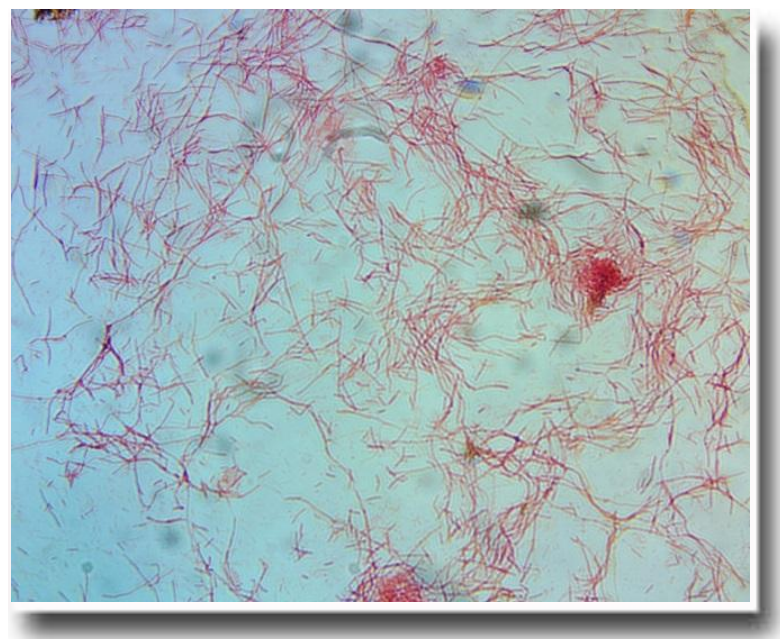

Pис. 5. Початок агрегації B. subtilis в біоплівку, 6 годин культивування. Фарбування водний розчин Конго червоний та карболовий фуксин. $\times 900$.

Результати досліду з вивчення здатності $B$. subtilis, утворювати біоплівку при спільному культивуванні 3 клінічними ізолятами $P$. 
aeruginosa корелюють 3 даними по вивченню відстроченого антагонізму. Нами встановлено, що B. subtilis утворюють біоплівку в тому числі в присутності P. Aeruginosa в 56,87\% (95\% ДІ 54,03-59,71) випадків. В таких лунках біоплівка була сформована B. subtilis, планктонні клітини $P$. aeruginosa поодинокі (рис. 8, 9). В 27,41\% (95\%ДІ 26,04-28,78) випадків за своєю архітектонікою біоплівка належала саме $P$. aeruginosa, проте виявляли чисельні планктонні клітини B. subtilis.

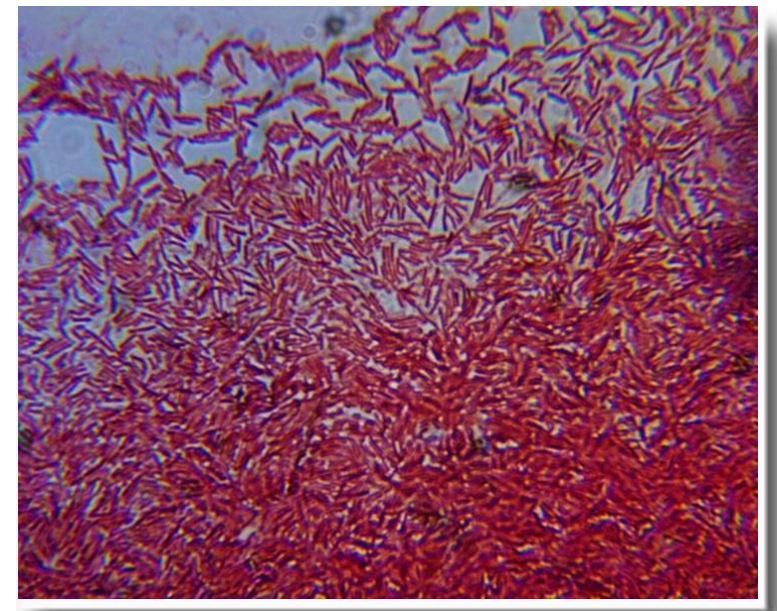

Pис. 6. Біоплівка B. Subtilis після 48 годин культивування. Забарвлення водний розчин Конго червоний та карболовий фуксин. $\times 900$.

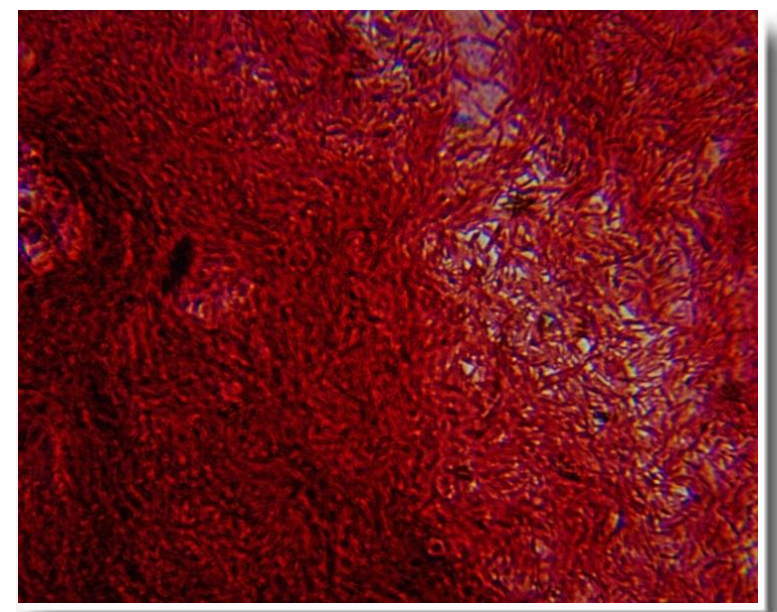

Рис.7. Біоплівка B. subtilis. після 72 годин культивування. Забарвлення водний розчин Конго червоний та карболовий фруксин. $\times 900$.

Можна виказати припущення, що в середині біоплівки, яку формують пробіотичні мікроорганізми, існує міжродова взаємодія по типу конкурентного антагонізму, в якій домінує came B. subtillis.

\section{Висновки}

1) Клінічні ізолятиР. aeruginosa, виділені від дітей з МВ чутливі до дії B. subtilis в експериментах з вивчення антагонізму;

2) Клінічні ізоляти P. aeruginosa, виділені від дітей з МВ, здатні до утворення біоплівок, що створює умови для тривалої персистенції; такі ізоляти володіють високою резистентністю до механічного кліренсу та дії протимікробних засобів;

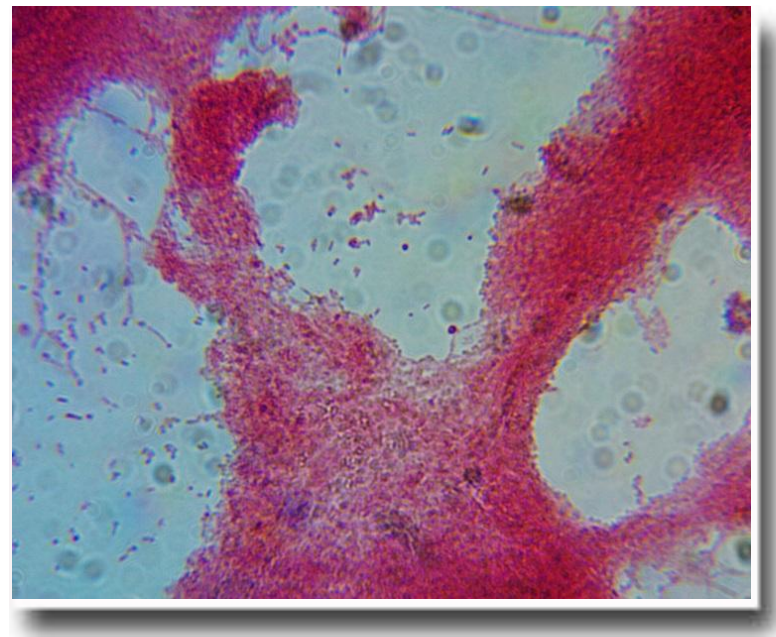

Рис. 8. Біоплівка при спільному культивуванні $B$. Subtilis та $P$. aeruginosa, 48 год. Забарвлення Конго червоний та карболовий фуксин. $\times 900$.

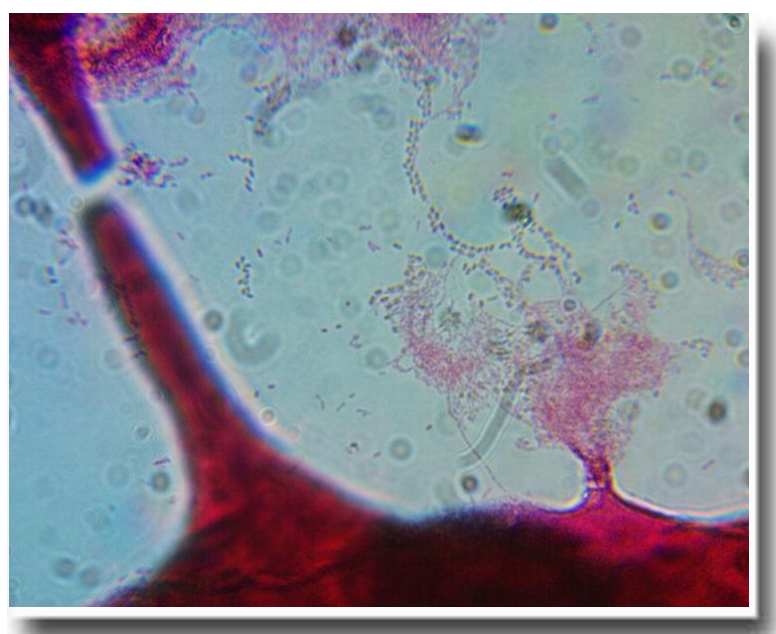

Рис. 9. Біоплівка при спільному культивуванні $B$. Subtilis та $P$. aeruginosa, 72 год. Забарвлення Конго червоний та карболовий фруксин. $\times 900$.

Біоплівкоутоврення клінічними ізолятами P. Aeruginosa in vitro може бути пригнічено дією B. subtilis, що, напевно, обумовлено антагоністичною взаємодією.

\section{Перспективи подальших досліджень}

Враховуючи доведений профіль безпеки $B$. Subtilis та широке застосування їх в якості пробіотиків, видається можливим використання бацил в якості засобу для санітарної обробки поверхонь 3 метою профілактики поширення $P$. aeruginosa-інфекції серед пацієнтів з МВ, що, безумовно, потребує подальших досліджень.

Інформація про конфлікт інтересів

Потенційних або явних конфліктів інтересів, що пов'язані 3 цим рукописом, на момент публікації не існує та не передбачається. 


\section{Літературні джерела \\ References}

1. Gilligan PH. Infections in patients with cystic fibrosis: diagnostic microbiology update. Clin Lab Med. 2014;34(2):197-217.

DOI: 10.1016/j.cll.2014.02.001.

2. IlchenkoSI. [Clinical and microbiological peculiarities of mucoviscidosis course in children of big industrial city].Pathologia. 2014;3(32):73-77. Ukrainian. DOI: 10.14739/2310-1237.2014.3.36980

3. Huang YJ, LiPuma JJ. The Microbiome in Cystic Fibrosis.Clin Chest Med. 2016;37(1):5967.DOI: 10.1016/j.ccm.2015.10.003.

4. Lezhenko GO, AbaturovOYe, PashkovaOYe, Pantyushenko LI. [Pathogenetic significance of antimicrobial peptides in the implementation of antibacterial protection in children with Cystic Fibrosis]. Zdoroverebenka. 2013;3(46):44-49. Ukrainian.

5. Pressler T, Bohmova C, Conway S, Dumcius S, Hjelte L, Hoiby N, Kollberg H, Tümmler B, Vavrova

V.ChronicPseudomonasaeruginosainfectiondefinitio n: EuroCareCFWorkingGroupreport.J CystFibros. 2011;(2):75-78. DOI: 10.1016/S15691993(11)60011-8.6. Lazareva AV, Tchebotar IV, Kryzhanovskaya OA., Tchebotar VI, Mayanskiy NA.[Pseudomonasaeruginosa: Pathogenicity, PathogenesisandDiseases].

ClinicalMicrobiologyandAntimicrobialChemotherap y. 2015;3(17):170-186.Russian.

7. Trofimenko YuYu. [Biological features of microflora colonizing endotracheal intubation tubes in intensive care units]. Thesis for the $\mathrm{PhD}$ degree in Medical Sciences. Vinnytsia National Medical University named after MI Pirogov. Vinnytsia, 2015 127 p. Ukrainian. URL: https://www.vnmu.edu.ua/downloads/other/dis_trofi menko.pdf

8. Hoppe JE, Harris JK, Zemanick ET. Assessing the Airway Microbiotain Cystic Fibrosis. Clinical Microbiology Newsletter. 2016;38(22):179184.

9. Galkin MB, Ivanytsia VO, Galkin BM, Filipova TO. [Biofilm matrix - chemical composition, structure, functions]. Microbiology \& Biotechnology. 2016;4:6-27. Ukrainian. DOI http://dx.doi.org/10.18524/2307-

4663.2016.4(36).86349.

10. Rakhmatullina MR, Nechayeva IA. [Biofilms of microorganisms and their role for the for- mation of resistance to antibacterial drugs]. Vestnik dermatologii i venerologii. 2015;(2):58-62. Russian.

11. Al-Marzooq F, AlBayat S, Sayyar F, Ishaq H, Nasralla H, Koutaich R, AlKawas S. Can probiotic cleaning solutions replace chemical disinfectants in dental clinics? Eur J Dent. 2018;12(4/):532539. DOI: 10.4103/ejd.ejd_124_18. PMCID: PMC6178676. PMID: 30369799.

12. Carling PC, Parry MF, Bruno-Murtha LA, Dick B. Improvingenvironmentalhygienein 27 intensivecareunitstodecrease multidrug-resistant bacterialtransmission. CritCareMed. 2010;38(4):1054-1059. https:// doi.org/10.1097/CCM.0b013e3181cdf705. PMID: 20081531

13. Rutala WA, Weber DJ. Selectionoftheidealdisinfectant. InfectControlHospEpidemiol. 2014;35(7):855-865. https://doi.org/10.1086/676877. PMID: 24915214.

14.La Fauci V, Costa GB, Anastasi F, Facciolà A, Grillo OC, SqueriR.

An Innovative Approach to Hospital Sanitization Using Probiotics: In Vitro and Field Trials. J MicrobBiochem Technol. 2015;7(3):160-164. DOI http://dx.doi.org/10.4172/1948-5948.1000198.

15.Caselli E, Brusaferro S, Coccagna M, Arnoldo L, Berloco F, Antonioli P. Reducing healthcare-associated infectionsincidenceby a probiotic-based sanitationsystem: A multicentre, prospective, interventionstudy. PLoS ONE. 2014;13(7):117: e0199616. https://doi.org/10.1371/ journal.pone.0199616.

URL: https://www.ncbi.nlm.nih.gov/pmc/articles/PMC604 2698/pdf/pone.0199616.pdf

16.Maria DA, Irene S, Piffanelli M, Bisi M, Mazzacane S, Caselli E. Efficient removal of hospital pathogens from hard surfaces by a combined use of bacteriophages and probiotics: potential assanitizing agents. Infection and Drug Resistance. 2018;11:1015-1026. DOI: 10.2147/IDR.S170071. PMCID: PMC6071622. PMID: 30104889.

17. Afinogenova AG, Kraeva LA, Ainogenov GE, Veretennikov VV. [Probiotic-based sanitation as alternatives to chemical disinfectants]. Russian Journal of Infection and Immunity. 2017;4(7):419424. Russian. doi: 10.15789/2220-7619-2017-4-419424.

Іщенко О.В., Юхименко А.О., Кошова I.П., Ільченко С.І., Степанський Д.О. Біоплівкоутворюючі властивості клінічних ізолятів pseudomonas aeruginosa, виділених від дітей хворих на муковісцидоз, та можливості впливу bacillussubtilis на них in vitro.

РЕФЕРАТ. Актуальність. Інфікування Pseudomonas aeruginosa визначає клінічний прогноз упацієнтів з муковісцидозом. Мукоїдніморфотипи P. Aeruginosa здатні до формування біоплівок та росту 
в них. 3 огляду на множинну резистентність біоплівок обговорюється можливість використання Bacillusspp. зметою санітарної обробки поверхонь, на яких можуть зберігатися патогени. Мета- вивчити біоплівкоутворюючі властивості клінічних ізолятів P. aeruginosa, виділених від дітей з муковісцидозом, та вплив на них Bacillus subtilis in vitro. Методи. Зразки мокротиння та/або слизу з глибокого мазку 3 задньої стінки глотки взяті від дітей хворих на муковісцидоз. Використано бактеріологічний, мікроскопічний, біохімічний та статистичний методи дослідження. Антагоністичні властивості $P$. Aeruginosa та B. Subtilis вивчали методом відстроченого антагонізму з використанням методики перпендикулярних штрихів та при спільному культивуванні в рідкому поживному середовищі з наступним висівом серійних розведень суспензій.Здатність до утворення біоплівоквизначали експрес-методом 3 використанням 96-луночних планшетів. Результати. При бактеріологічному дослідженні встановили, що P. aeruginosa виділяється з 34,21\% (95\% ДІ 32,50-35,92) зразків. При вивченні відстроченого антагонізму між P. Aeruginosa і B. subtilis, а також при їх спільному культивуванні в рідкому поживному середовищі виявили, що B. Subtilis володіють прямим помірним антагонізмом по відношенню до P. aeruginosa. Після спільної культивації культура бацил давала рясний ріст в усіх дослідах при всіх повтореннях, обмежуючи ріст P. aeruginosa. Серед виділених ізолятів $P$. aeruginosa встановлено здатність до біоплівкоутворення в 76,92\% (95\% ДІ 73,02-80,77) випадків, серед зразків B. subtilis - в 100\%. При спільному культивуванні $B$. subtilis утворювали біоплівку в присутностіP. aeruginosa в більшості випадків. Висновки. Клінічні ізоляти $P$. aeruginosa, виділені від дітей з муковісцидозом помірно чутливі до дії B. subtilisinvitro. Біоплівкоутворення P. Aeruginosa in vitro може бути пригнічене дією B. subtilis.

Ключові слова: муковісцидоз, $P$. aeruginosa, мукоїдний фенотип, біоплівка, B. subtilis, антагонізм.

\begin{abstract}
Ищенко О.В., Ефименко А.О., Кошевая И.П., Ильченко С.И., Степанский Д.А. Биопленкообразующие свойства клинических изолятов Pseudomonas aeruginosa, выделенных от детей больных муковисцидозом, и возможности влияния Bacillus subtilis на них in vitro.
\end{abstract}

РЕФЕРАТ. Актуальность. Инфицирование Pseudomonas aeruginosa определяет клинический прогноз у пациентов с муковисцидозом. Мукоидный фенотип P. Aeruginosa способен к формированию биопленок и роста в них. Учитывая множественную резистентность микроорганизмов, образующих биопленки, обсуждается возможность использования Bacillusspp. с целью санитарной обработки поверхностей, на которых могут сохраняться патогены. Цель- изучить биопленкообразующую способность клинических изолятов P. aeruginosa, выделенных от детей больных муковисцидозом, и влияние на них $B$. Subtilis in vitro. Методы. Образцы мокроты и/или слизи из глубокого мазка с задней стенки глотки были отобраны у детей больных муковисцидозом. Использованы бактериологический, микроскопический, биохимический и статистический методы исследования. Антагонистические свойства P. aeruginosa и B. subtilis изучали методом отсроченного антагонизма с использованием методики перпендикулярных штрихов и при совместном культивировании в жидкой питательной среде с последующим высевомсерийных разведений. Способность к образованию биопленок определяли экспресс-методом с использованием 96-луночных планшетов. Результаты. При бактериологическом исследовании установили,что $P$. aeruginosa выделяется из 34,21\% (95\% ДИ 32,50-35,92) образцов. При изучении отсроченного антагонизма между $P$. aeruginosa и $B$. subtilis и их совместного культивирования в жидкой питательной среде обнаружили, что $B$. subtilis обладают прямым умеренным антагонизмом по отношению к P. aeruginosa. После совместного культивирования культура бацилл давала обильный рост во всех опытах при всех повторениях, ограничивая рост P. aeruginosa. Среди выделенных изолятов $P$. aeruginosa установлена способность к биопленкообразованию в 76,92\% (95\% ДИ 73,02-80,77) случаев, среди образцов B. subtilisв $100 \%$. При совместном культивировании B. subtilis образовывали биопленку в присутствии $P$. aeruginosa в большинстве случаев. Выводы. Клиническиеизоляты P. aeruginosa умеренно чувствительны к действию B. Subtilis in vitro. Биопленкообразование клинических изолятов P. Aeruginosa in vitro может быть подавлена действием B. subtilis.

Ключевые слова: муковисцидоз, P. aeruginosa, мукоидный фенотип, биопленка, B. subtilis, антагонизм. 